Article

\title{
Pomegranate Juice Extract Decreases Cisplatin Toxicity on Peripheral Blood Mononuclear Cells
}

\author{
Mohamad Nasser ${ }^{1,2}$, Ziad Damaj ${ }^{1}$, Akram Hijazi ${ }^{1, *}$, Othmane Merah ${ }^{3,4, * \mathbb{C}}$, Batoul Al-Khatib ${ }^{1}$, \\ Nadine Hijazi ${ }^{1}$, Christine Trabolsi ${ }^{5}$, Raghida Damaj ${ }^{1}$ and Mouhamad Nasser ${ }^{6,7}$ \\ 1 Doctoral School of Science and Technology, Research Platform for Environmental Science (PRASE), \\ Lebanese University, Beirut P.O. Box 5, Lebanon; mohamednasser@hotmail.fr (M.N.); \\ damajz@hotmail.fr (Z.D.); batool.khatib93@hotmail.com (B.A.-K.); nadinehijazi96@hotmail.com (N.H.); \\ r.damaj@ul.edu.lb (R.D.) \\ 2 Rammal Hassan Rammal Research Laboratory, Physiotoxicity (PhyTox), Faculty of Sciences, \\ Lebanese University, Nabatieh 1700, Lebanon \\ 3 Laboratoire de Chimie Agroindustrielle, LCA, Université de Toulouse, INRA, 31030 Toulouse, France \\ 4 Département Génie Biologique, IUT A, Université Paul Sabatier, 32000 Auch, France \\ 5 Faculty of Medicine, Lebanese University, Beirut P.O. Box 5, Lebanon; christinetrabolsi9@gmail.com \\ 6 Department of Respiratory Medicine, National Coordinating Reference Centre for Rare Pulmonary Diseases, \\ Louis Pradel Hospital, University Hospital of Lyon, 69677 Lyon, France; mohammad-nasser@hotmail.com \\ 7 Claude Bernard University Lyon 1, UMR754, IVPC, 69008 Lyon, France \\ * Correspondence: akram.hijazi@ul.edu.lb (A.H.); othmane.merah@ensiacet.fr (O.M.); \\ Tel.: +961-71905768 (A.H.); +33-534323523 (O.M.)
}

Received: 26 August 2020; Accepted: 13 October 2020; Published: 15 October 2020

\begin{abstract}
Background: Lung cancer is one of the most prevalent cancers worldwide. Chemotherapy regimens, targeted against lung cancer, are considered an effective treatment; albeit with multiple fatal side effects. An alternative strategy, nowadays, is using natural products. Medicinal plants have been used, in combination with chemotherapy, to ameliorate side effects. This study aims to investigate the antitumor effect of pomegranate juice (Punica granatum) on human lung adenocarcinoma basal epithelial cells (A549), to check the effect, when combined with low dose cisplatin (CDDP), at different doses. We also have evaluated the potential protective effect of pomegranate on normal peripheral blood mononuclear cells (PBMC). Methods: Phytochemical screening of the extract was done using standard classical tests. Total phenolic and sugar contents were determined using the Folin-Ciocalteu and anthrone reagents, respectively. The antioxidant activity of pomegranate was estimated by the 2,2-diphenyl-1-picrylhydrazyl (DPPH) method. The viability of A549 cells and PBMC was evaluated using the neutral red assay. Results: Our results demonstrated that Punica granatum or pomegranate juice (with different concentrations: 150, 300, $600 \mu \mathrm{g} / \mathrm{mL}$ ) contained high levels of flavonoids, alkaloids, tanins, lignins, terpenoids, and phenols. The DPPH method showed that pomegranate juice had a strong antioxidant scavenging activity. Neutral red showed that combining pomegranate juice with low dose CDDP $(8 \mu \mathrm{g} / \mathrm{mL})$ decreased the cell viability of A549 cells, by $64 \%$, compared to treatment with CDDP or pomegranate alone. When added to low dose CDDP, pomegranate increased the viability of normal PBMC cells by $46 \%$. Conclusions: These results demonstrated that pomegranate could potentiate the anticancer effect of low dose CDDP on human lung adenocarcinoma cells (A549 cells) and could as well decrease its toxicity on PBMC.
\end{abstract}

Keywords: lung cancer; Punica granatum; cisplatin; A549 cells; PBMC 


\section{Introduction}

Lung cancer is the main leading cause of cancer-related death in men, and the second in women [1]. Patients with lung cancer have a five-year survival rate of $15.6 \%$ in the United States [1]. Lung cancer is thought to arise from the respiratory epithelial cells, and it is widely classified into two main types: small cell lung and non-small cell lung cancer, accounting for $15 \%$ and $85 \%$ of cases, respectively. Non-small cell lung cancer is further subdivided into: adenocarcinoma (38.5\% of all lung cancer cases), squamous cell carcinoma (20\%), and large cell carcinoma (2.9\%) [1].

Surgery can be curative in early stages; however, around half of patients are diagnosed in advanced stage, when lung resection cannot be entertained [2]. In such cases, chemotherapy and radiation therapy are used to increase relapse-free survival, or as a part of compassionate treatment in patients with compression related manifestations [3].

An appreciable proportion of patients necessitate chemotherapy following surgery, known as 'adjuvant chemotherapy', to decrease recurrence rate. This is particularly true for patients with stage II and IIIA disease [2].

The chemotherapy treatment plan often consists of a combination of drugs. Most commonly used drugs are cisplatin (CDDP), carboplatin, docetaxel, gemcitabine, paclitaxel, vinorelbine, and pemetrexed [3]. CDDP or cis-diamminedichloroplatinum (II) is a well-known platinum-based chemotherapeutic agent, used for the treatment of different neoplasms as lung, bladder, head and neck, and ovarian malignancies. CDDP induces apoptosis in tumor cells through the inhibition of DNA synthesis and repair mechanisms. Nevertheless, CDDP has many side effects such as: severe kidney problems, allergic reactions, immunity disease, gastrointestinal disorders, hemorrhage, hearing loss, and hematological toxic effects, such as anaemia, leukopenia, neutropenia, and thrombocytopenia [4-6].

Some medicinal plants, owing to their anticancer properties, have been used for treatment of distinct cancers like lung, skin, and bladder cancers [7]. Lebanon is a country rich in medicinal plants; one such plant is pomegranate [8].

Punica granatum or pomegranate is an ancient edible fruit that has been used for centuries as a medicine. Recent studies demonstrated antioxidant, antimicrobial, anticarcinogenic, anti-inflammatory, and antiviral properties of this plant. These properties are due to the presence of phytochemicals, including phenolics (e.g., flavonoids, tannins), terpenoids, and alkaloids [9]. Polyphenols, such as flavonoids, are ubiquitously present in fruits and vegetables. It has evinced the ability to downregulate the expression of various genes, proteins, and signaling cascades that are responsible for tumor growth and progression; making them potential therapeutic agents for cancer patients [10]. Pomegranate exerts anticancer and antioxidant activities, which are generally attributed to its high content of polyphenols, and its role in neutralizing free radicals. Pomegranate juice and pomegranate extracts inhibit the growth of prostate cancer cells in in vitro cultures, and also inhibit cell proliferation and induce apoptosis in human breast cancer cells, pancreatic cancer cells, and even in colon and hepatocellular carcinoma cell lines [11]. Moreover, pomegranate polyphenol has potent anticancer activity in breast, lung, and cervical cancer cells [12].

In order to decrease chemotherapy-related toxicity, cisplatin dose is reduced; a strategy that would mitigate its antineoplastic activity. In a previous study of ours, we demonstrated that combining pomegranate to low dose cisplatin on human lung adenocarcinoma (A549) cell lines, decreased their cell viability in comparison to those treated with chemotherapy drugs alone [13]. Yet, the protective effect of pomegranate on peripheral blood mononuclear cells (PBMC) has not been studied.

\section{Materials and Methods}

\subsection{Preparation of Pomegranate Fruit Extract}

Pomegranate fruit was taken from South Lebanon (Nmairiyeh village) which is at a height of $400 \mathrm{~m}$ from the surface of water. The fruit was peeled and squeezed then filtered to obtain the pomegranate juice. The juice was placed on ice at $-80{ }^{\circ} \mathrm{C}$ for about $2 \mathrm{~h}$. It was then kept in the lyophilizer for 
3 days to remove water and convert them to powder. The powder was stored in a desiccator at room temperature.

\subsection{Chemical Tests}

\subsubsection{Phytochemical Screening Test}

Pomegranate juice was centrifuged at $2500 \mathrm{rpm}$ for $5 \mathrm{~min}$ at a temperature of $22{ }^{\circ} \mathrm{C}$, and then the supernatant was filtered by filter paper using Buchner vacuum. This filtrate was used for the qualitative detection of primary and secondary metabolites according to Nasser et al. [14] (Table 1).

Table 1. Detection of primary and secondary metabolites by phytochemical screening

\begin{tabular}{|c|c|c|}
\hline Plant Constituents & Reagents Added & Color \\
\hline Phenolic acids & $\mathrm{FeCl}_{3}(1 \%)+\mathrm{K}_{3}\left(\mathrm{Fe}(\mathrm{CN})_{6}\right)(1 \%)$ & Greenish Blue color \\
\hline Terpenoids & Chloroform + concentrated sulfuric acid & Reddish brown color in the surface \\
\hline Flavonoids & $\mathrm{KOH}$ (potassium hydroxide $50 \%$ ) & Yellow \\
\hline Quinones & $\mathrm{HCl}$ concentrated & Precipitate or yellow color \\
\hline Alkaloids & Dragendroff reagent & Reddish Orange precipitate/turbidity \\
\hline Tannins & $\left(\mathrm{FeCl}_{2}(1 \%)\right)$ & Blue color \\
\hline Resins & Acetone + water + agitation & Turbidity \\
\hline Saponins & Vigorous shaking & Layer of foam \\
\hline Reducing sugar & Water + fehlings $(\mathrm{A}+\mathrm{B})+$ boil & Brick-red precipitate \\
\hline Anthraquinones & $\operatorname{HCl}(10 \%)+$ boil & Precipitate \\
\hline Proteins and amino acids & Ninhydrin $(0.25 \%)+$ boil & Blue color \\
\hline Phlabotannins & $\mathrm{HCl}(1 \%)+$ boil $5 \mathrm{~min}+$ cooling & Red precipitate \\
\hline Flavanones & $\mathrm{H}_{2} \mathrm{SO}_{4}$ concentrated & Purple red color \\
\hline Diterpenes & Copper sulfate & Green color \\
\hline Sterols and steroids & Chloroform $+\mathrm{H}_{2} \mathrm{SO}_{4}$ concentrated & $\begin{array}{l}\text { Red color of upper layer }+ \text { greenish } \\
\text { yellow fluorescence in acidic layer }\end{array}$ \\
\hline Anthocyanins & $\mathrm{NaOH}(10 \%)$ & Blue color \\
\hline Lignines & Safranin & Pink color \\
\hline Cardiac glycosides & $\begin{array}{c}\text { Acetic acid glacial }+\mathrm{FeCl}_{3}(5 \%)+\mathrm{H}_{2} \mathrm{SO}_{4} \\
\text { concentrated }\end{array}$ & Purple ring + brown ring + green ring \\
\hline Fixed oils and fatty acids & Spot test & Oil spot \\
\hline
\end{tabular}

\subsubsection{Antioxidant Test (DPPH Radical Scavenging Method)}

DPPH (2,2-diphenyl-1-picrylhydrazyl) from Sigma-Aldrich, is composed of stable free radical molecules which has a strong purple color that can be measured spectrophotometrically. In the presence of compounds capable of transferring an electron or donating hydrogen, DPPH becomes discolored, indicating therefore the antioxidant activity of the tested compound. In this study, radical scavenging activity was determined [15]. DPPH solution was prepared by dissolving $0.0012 \mathrm{~g}$ of DPPH powder in $50 \mathrm{~mL}$ of methanol. The extract was prepared by dissolving $10 \mathrm{mg}$ of pomegranate powder in $0.5 \mathrm{~mL}$ distilled water and $0.5 \mathrm{~mL}$ of methanol. After that, $2 \mathrm{~mL}$ of DPPH solution was mixed with $50 \mu \mathrm{L}$ of the extract solution and the mixed solution was put in dark for $30 \mathrm{~min}$. The absorbance was then read at $515 \mathrm{~nm}$ on UV-vis spectrophotometer. The antioxidant activity was calculated according to the equation

$$
\% \text { Antioxidant activity }=100 \times(\text { ABS control }- \text { ABS sample }) / A B S \text { control }
$$

The absorbance ABS control is the absorbance of DPPH + solvent; ABS sample is the absorbance of the DPPH + sample, where the control was prepared by taking $2 \mathrm{~mL}$ of the prepared DPPH solution $(\mathrm{DPPH}+$ methanol) without the extract. 


\subsubsection{Carbohydrates Test}

Anthrone (10H-Anthracen-9-one) from Sigma-Aldrich, is a tricyclic aromatic ketone, used for colorimetric determination of carbohydrates. In this method, carbohydrates are dehydrated with concentrated $\mathrm{H}_{2} \mathrm{SO}_{4}$ to form furfural which condenses with anthrone to form a green color complex, measured spectrophotometrically ultimately. First, $100 \mathrm{mg}$ of pomegranate powder were macerated in $5.25 \mathrm{~mL}$ of $80 \%$ ethanol for $12 \mathrm{~h}$. This solution was then centrifuged at $4000 \mathrm{rpm}$ for $10 \mathrm{~min}$. The supernatant was then diluted 1000 times to obtain solution A. Solution B was prepared by dissolving $1 \mathrm{~g}$ of anthrone in $500 \mathrm{~mL}$ concentrated sulfuric acid. Solution B (4 mL) was added to solution $\mathrm{A}(2 \mathrm{~mL})$ and vortexed for $1 \mathrm{~min}$ and then put at $92{ }^{\circ} \mathrm{C}$ for $8 \mathrm{~min}$. The mixture was placed in dark for $30 \mathrm{~min}$ and then the absorbance was measured at $585 \mathrm{~nm}$. The blank tube was prepared similarly; yet, $2 \mathrm{~mL}$ of solution A were used with $2 \mathrm{~mL}$ of distilled water.

\subsubsection{Phenol Content Test}

Folin-Ciocalteu reagent was a mixture of phosphomolbdate and phosphotungtate used for colorimetric determination of phenolic compounds by the method of Farhan et al. [16], with some modifications. This test was performed through the following steps. First, the sample was prepared by dissolving $25 \mathrm{mg}$ of pomegranate powder in $10 \mathrm{~mL}$ distilled water. Distilled water $(3.16 \mathrm{~mL})$ and Folin-Ciocalteu reagent $(200 \mu \mathrm{L})$ were added to $40 \mu \mathrm{L}$ of the prepared sample and vortexed together. After $5 \mathrm{~min}, 600 \mu \mathrm{L}$ of $\mathrm{Na}_{2} \mathrm{CO}_{3}$ solution, prepared by dissolving $20 \mathrm{~g} \mathrm{Na}_{2} \mathrm{CO}_{3}$ in $100 \mathrm{~mL}$ distilled water, were added to the vortexed mixture and then vortexed for $1 \mathrm{~min}$. They were heated in water bath at $40{ }^{\circ} \mathrm{C}$ for $30 \mathrm{~min}$. The absorbance was measured at $765 \mathrm{~nm}$ after cooling the sample for $10 \mathrm{~min}$. The blank tube was prepared by similar steps but instead of $40 \mu \mathrm{L}$ of prepared sample, $40 \mu \mathrm{L}$ distilled water was used.

\subsubsection{Dry Matter Test}

Biomass is usually determined on a dry matter basis, which is the weight of plant material after the moisture within it, had been extracted. In this test, $1 \mathrm{~g}$ of pomegranate powder was weighted and put in oven at $100^{\circ} \mathrm{C}$ for $24 \mathrm{~h}$. The percentage of dry matter was determined using the equation

$$
\% \text { Dry matter }=\left(\mathrm{M}_{2}-\mathrm{M}_{0}\right) \times 100 /\left(\mathrm{M}_{1}-\mathrm{M}_{0}\right)
$$

where $\mathrm{M}_{0}$ is the mass of empty beaker, $\mathrm{M}_{1}$ is the mass of beaker with extract, and $\mathrm{M}_{2}$ is the mass of beaker with extract after drying in oven.

\subsection{Cell Culture and Treatment}

\subsubsection{A549 Cells}

The A549 cells, obtained from ATCC, Manassas, VA, USA, were grown in T75 cell culture flasks in a total volume of $10 \mathrm{~mL}$ of Dulbecco's modified Eagle medium (DMEM) and supplemented with $10 \%$ fetal bovine serum, $1 \%$ penicillin/streptomycin and kept at $37{ }^{\circ} \mathrm{C}, 5 \% \mathrm{CO}_{2}$ in humidified air in an incubator.

\subsubsection{Control Normal Cells}

Peripheral blood mononuclear cells (PBMC), were isolated from human healthy volunteers blood and then underwent density gradient centrifugation. Briefly, blood is diluted by PBS in a 1:1 ratio. A $4 \mathrm{~mL}$ of diluted blood were added to $2 \mathrm{~mL}$ ficoll, and centrifuged at $400 \times \mathrm{g}$ for $30 \mathrm{~min}$ without brake. Carefully then isolate the buffy coat layer containing PBMC. Washed PBMC by $5 \mathrm{~mL}$ PBS and centrifuged at $300 \times g$ for $15 \mathrm{~min}$. Supernatant was removed and washed second time by $5 \mathrm{~mL}$, then centrifuged at $200 \times g$ for $15 \mathrm{~min}$. The cells obtained were resuspended in RPMI medium 
supplemented with $10 \%$ fetal bovine serum, $1 \%$ penicillin/streptomycin, and seeded in 24-well plates and then incubated at $37^{\circ} \mathrm{C}$ with $5 \% \mathrm{CO}_{2}$ humidified air.

\subsubsection{Treatment of Cells}

Cells' treatment was done by lyophilized pomegranate dissolved in medium specific for each cell type by vortex and filtered by a filter of $0.22 \mu \mathrm{m}$ diameter. Cells were seeded in a 24-well plate at a concentration of 100,000 cells/well then treated with different concentrations of pomegranate, CDDP (from Mylan-France), and combination of both.

The evaluation of antiproliferative activity was done by measuring cell viability of A549 cells and PBMC (control cells) after $24 \mathrm{~h}$ of treatment with increasing concentrations of CDDP $(2,4,8$, and $12 \mu \mathrm{g} / \mathrm{mL}$ ) and with pomegranate juice extract $(150,300$, and $600 \mu \mathrm{g} / \mathrm{mL})$. Moreover, cells were treated with different combinations of pomegranate juice $(150$ and $300 \mu \mathrm{g} / \mathrm{mL})$ and CDDP $(2,4$, and $8 \mu \mathrm{g} / \mathrm{mL}$ ).

\subsection{Viability Tests}

Neutral Red Uptake Assay

Cell viability was measured by performing neutral red assay. Briefly, after $24 \mathrm{~h}$ of treatment of A549 cells, medium was aspirated from wells and washed one time with phosphate buffered saline (PBS) then incubated for $3 \mathrm{~h}$ in a medium containing neutral red solution $(40 \mu \mathrm{g} / \mathrm{mL})$ from Sigma-Aldrich. Then the media were discarded and the cells were washed twice with PBS. After that, cells were incubated for few minutes in lysing solution (200 $\mu \mathrm{L} /$ well) formed of $1 \%$ acetic acid and $50 \%$ ethanol to extract the dye.

PBMC were spined and the medium was removed. Cells were incubated in each well in neutral red solution $(40 \mu \mathrm{g} / \mathrm{mL})$ for $3 \mathrm{~h}$. After incubation, cells were spined down and the staining solution was removed then washed once with PBS and spined to remove washing solution. Then, lysing solution ( $200 \mu \mathrm{L} /$ well) was used for A549 cells and incubated for few minutes.

The solutions of each well were then transferred to 96-well plate and read at $450 \mathrm{~nm}$ by microplate reader [17].

\subsection{Statistical Analysis}

Statistical analysis was performed using GraphPad Prism 5. Each value represents the mean \pm the standard error of the mean (SEM). One-way ANOVA was used to assess cell viability, and differences between groups were analyzed by Bonferroni test. Groups that are significantly different from the control are indicated in the Figures as ${ }^{*} p<0.05,{ }^{* *} p<0.01$, and ${ }^{* * *} p<0.001$.

\section{Results}

\subsection{Phytochemical Screening Test}

Phytochemicals are bioactive molecules present in plants and involved in protecting human health. Qualitative tests of these compounds showed the presence of alkaloids, terpenoids, as well as phenols, including tannins, flavonoids and anthocyanins. Results of these tests are represented in Table 2. 
Table 2. Chemical composition of pomegranate juice.

\begin{tabular}{cc}
\hline Bioactive Molecule & Result \\
\hline Reducing sugar & + \\
Anthraquinones & - \\
Proteins and amino acids & - \\
Phlabotannins & - \\
Alkaloids & + \\
Tanins & + \\
Resins & - \\
Terpenoids & + \\
Flavonoids & + \\
Quinones & - \\
\hline
\end{tabular}

Table 2. Cont.

\begin{tabular}{cc}
\hline Bioactive Molecule & Result \\
\hline Sterols et steroids & + \\
Diterpenes & - \\
Anthocyanins & + \\
Flavanones & + \\
Lignins & + \\
Cardiac glycosides & - \\
Saponins & - \\
Phenols & + \\
Fixed oils and fatty acids & - \\
\hline +: presence, $-:$ absence. &
\end{tabular}

\subsection{Antioxidant Test (DPPH Radical Scavenging Method)}

The antioxidant activity test showed that as the concentration of pomegranate juice increases the antioxidant activity increases too. This was observed by the decrease of violet color intensity as the concentration was increased from 10 to $20 \mathrm{mg} / \mathrm{mL}$. The DPPH radical scavenging activity was $35.56 \pm 0.89 \mathrm{TE} \mu \mathrm{mol} / \mathrm{g}$ of extract. The optical density decreased as the concentration of pomegranate juice increased. In addition, the antioxidant activity of DPPH was more efficient with methanol than with ethanol. This antioxidant activity was $70 \%$ with methanol compared to $33 \%$ with ethanol knowing that methanol is more polar than ethanol and can extract more chemicals [18]. This was also observed by the transformation of violet color to yellow color as the concentration of DPPH was increased from 0.1 to $0.5 \mathrm{mg} / \mathrm{mL}$.

\subsection{Carbohydrate Test}

Anthrone is widely used as a reagent in the quantitative determination of carbohydrates in plants. This test showed the presence of high amount of carbohydrates in pomegranate juice in which it was $69.29 \pm 2.5 \%$ (Table 3 ).

Table 3. Carbohydrates, phenol, and dry matter content in pomegranate juice

\begin{tabular}{cc}
\hline Test & Content \\
\hline Amount of carbohydrates & $69.29 \%$ \\
\hline Total phenol content & $6.93 \mathrm{mg} \mathrm{GAE} / \mathrm{g}$ \\
\hline The percentage of dry matter & $81.1463 \%$ \\
\hline
\end{tabular}




\subsection{Phenol Content Test}

The total phenol content of pomegranate juice extract was estimated using Folin-Ciocalteu assay. It was found to be $6.93 \pm 0.09 \mathrm{mg} \mathrm{GAE} / \mathrm{g}$ of pomegranate juice extract (Table 3).

\subsection{Dry Matter Test}

The most common way to determine is through the evaporation of water from the extract. The percentage of dry matter was $81.1463 \%$ (Table 3 ).

\subsection{Cell Viability Results}

\subsubsection{Neutral Red Assay}

The optical density decreased after treatment as a function of concentration. Viable cells can take up neutral red via active transport and incorporate the dye into their lysosomes; whereas non-viable cells cannot take up this chromophore. The decrease in optical density for treated wells compared to control reflects the decrease in cell viability after treatment.

\subsubsection{Treatment of A549 Cells with CDDP in a Dose-Dependent Manner}

Treatment with CDDP for $24 \mathrm{~h}$ at increased concentrations $(2,4,8$, and $12 \mu \mathrm{g} / \mathrm{mL})$ caused a decrease in cell viability of A549 cells compared to untreated cells (control). At concentration $2 \mu \mathrm{g} / \mathrm{mL}$, cell viability decreased by $6 \%$ but there was no significant difference in comparison to the control. On the other hand, a significant decrease in cell viability compared to the control was seen for cells treated with concentrations 4,8 , and $12 \mu \mathrm{g} / \mathrm{mL}$ by $34 \%, 40 \%$, and $85 \%$, respectively (Figure 1 ).

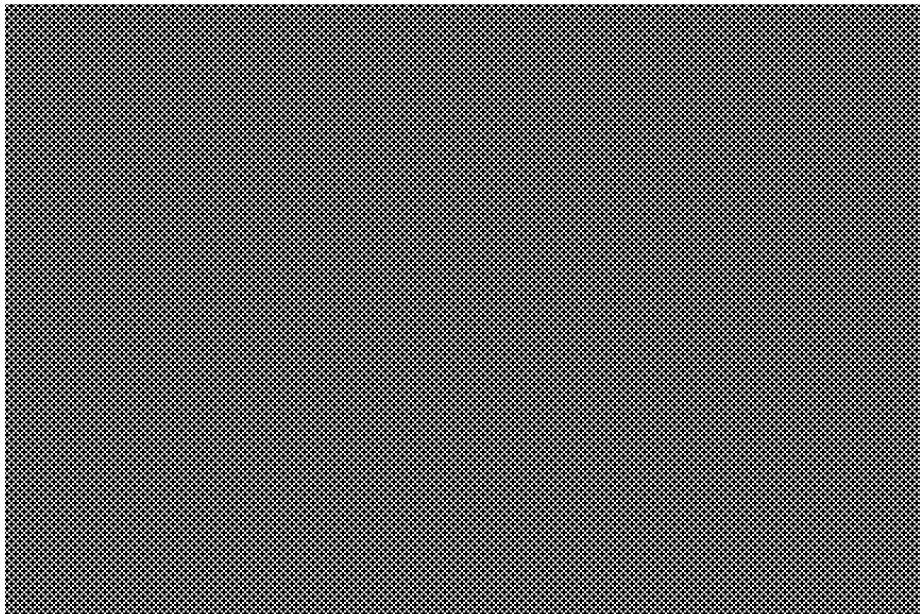

Figure 1. Effect of CDDP on cell viability of A549 cells after $24 \mathrm{~h}$ of treatment. ns: non significant $p>0.05,{ }^{* * *} p<0.001$ in comparison to control. The number of samples is $n=6$. (CDDP:cisplatin).

\subsubsection{Treatment of A549 Cells with Pomegranate in a Dose-Dependent Manner}

Treatment of A549 cells with pomegranate juice extract at increased concentrations showed a decrease in cell viability. No significant difference was observed for concentration $150 \mu \mathrm{g} / \mathrm{mL}$ in which cell viability was decreased by $5 \%$ only, however, a significant decrease was seen with higher concentrations of 300 and $600 \mu \mathrm{g} / \mathrm{mL}$ ( $26 \%$ and $49 \%$, respectively) (Figure 2). 


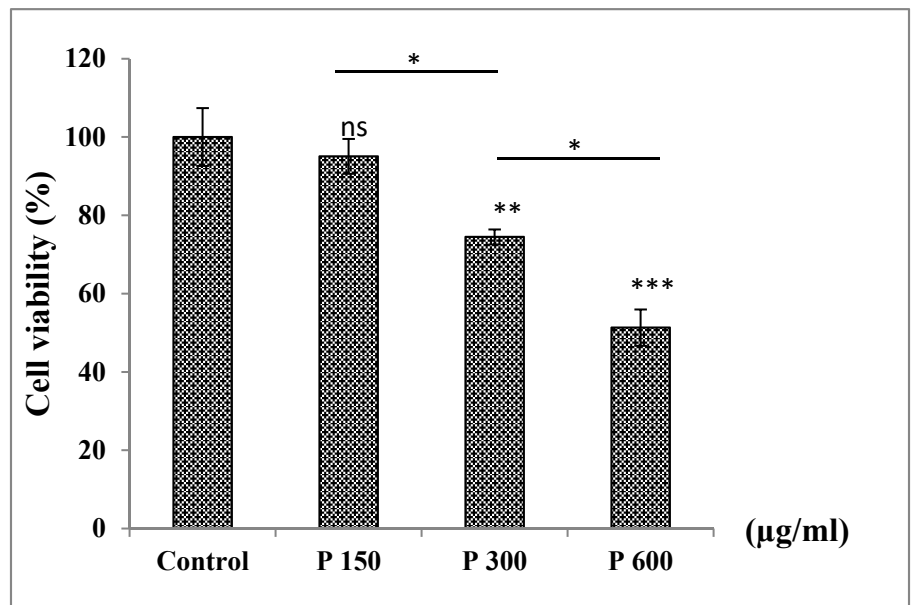

Figure 2. Effect of pomegranate on cell viability of A549 cells after $24 \mathrm{~h}$ of treatment. ns: non significant ${ }^{*} p>0.05,{ }^{* *} p<0.01,{ }^{* * *} p<0.001$ in comparison to the control. The number of samples is $n=6$. (P: pomegranate).

\subsubsection{Effect of Combination of Pomegranate with CDDP on A549 Cell Viability}

Neutral red results showed decreased cell viability when pomegranate was combined with CDDP compared to control. Cells treated with $150 \mu \mathrm{g} / \mathrm{mL}$ pomegranate extract combined to 2, 4, and $8 \mu \mathrm{g} / \mathrm{mL}$ of CDDP showed no significant decrease in cell viability compared to CDDP alone $(2,4$, and $8 \mu \mathrm{g} / \mathrm{mL})$. However, at this concentration $(150 \mu \mathrm{g} / \mathrm{mL})$, pomegranate juice showed a proliferative effect. After combination of pomegranate $(150 \mu \mathrm{g} / \mathrm{mL})$ with $8 \mu \mathrm{g} / \mathrm{mL}$ of CDDP, there was a debate between pomegranate at this concentration and the antiproliferative effect of $8 \mu \mathrm{g} / \mathrm{mL}$ CDDP (Figure 3).

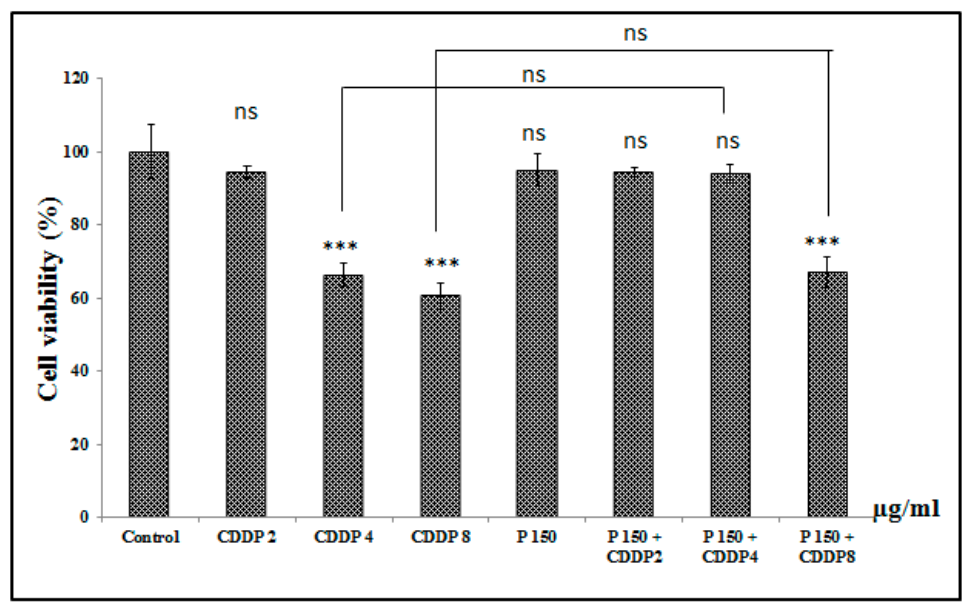

Figure 3. Effect of combining pomegranate $(150 \mu \mathrm{g} / \mathrm{mL})$ with CDDP on cell viability of A549 cells after 24 h of treatment. ns: non significant $p>0.05,{ }^{* * *} p<0.001$ in comparison to control. The number of samples is $n=6$ (CDDP: cisplatin, P: pomegranate juice).

On the other hand, treatment with pomegranate $(300 \mu \mathrm{g} / \mathrm{mL})$ combined with the three concentrations of $\operatorname{CDDP}(2,4$, and $8 \mu \mathrm{g} / \mathrm{mL})$ showed a significant decrease in cell viability with a percentage decrease of $27 \%, 45 \%$, and $64 \%$, respectively. In addition, a significant difference was observed for the combination of pomegranate $(300 \mu \mathrm{g} / \mathrm{mL})$ with CDDP $(8 \mu \mathrm{g} / \mathrm{mL})$ in comparison to CDDP $(8 \mu \mathrm{g} / \mathrm{mL})$ alone. As well, there was a significant difference between pomegranate $(300 \mu \mathrm{g} / \mathrm{mL})$ alone and the combination with CDDP $(8 \mu \mathrm{g} / \mathrm{mL})$. Then, this concentration $300 \mu \mathrm{g} / \mathrm{mL}$ is the optimal concentration used in combination with CDDP 8 for the anti-cancer effect (Figure 4). 


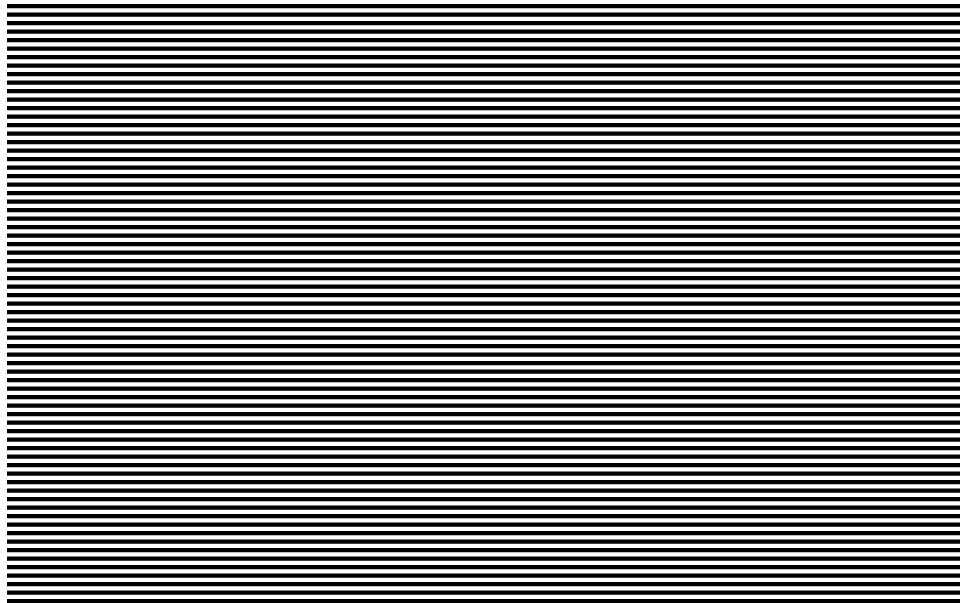

Figure 4. Effect of combining pomegranate $(300 \mu \mathrm{g} / \mathrm{mL})$ with CDDP on cell viability of A549 cells after 24 h of treatment. ns: non significant $p>0.05,{ }^{* *} p<0.01,{ }^{* * *} p<0.001$ in comparison to control, $\# \# p<0.01$. The number of samples is $n=6$. (CDDP: cisplatin, P: pomegranate juice).

\subsubsection{Effect of Combination of Pomegranate and CDDP on Normal PBMC}

Treatment with increased concentrations of CDDP for $24 \mathrm{~h}$ showed a significant decrease in cell viability of PBMC for concentrations 8 and $12 \mu \mathrm{g} / \mathrm{mL}$ with a percentage decrease of $43 \%$ and $50 \%$, respectively (Figure 5).

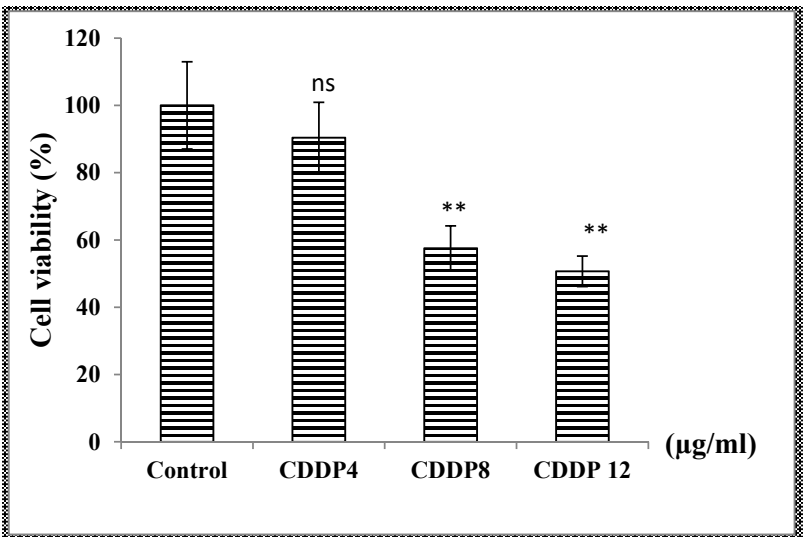

Figure 5. Effect of CDDP on cell viability of control normal PBMC cells after $24 \mathrm{~h}$ of treatment. ns: non significant $p>0.05,{ }^{* *} p<0.01$ by comparison to the control. The number of samples is $n=4$ (CDDP: cisplatin).

However, treatment with pomegranate alone, or in combination with CDDP, had no significant effect on cell viability. Increased concentration of pomegranate $(300 \mu \mathrm{g} / \mathrm{mL})$ had a significant increase in PBMC cell viability by $46 \%$ compared to untreated cells (control) (Figure 6A,B). 

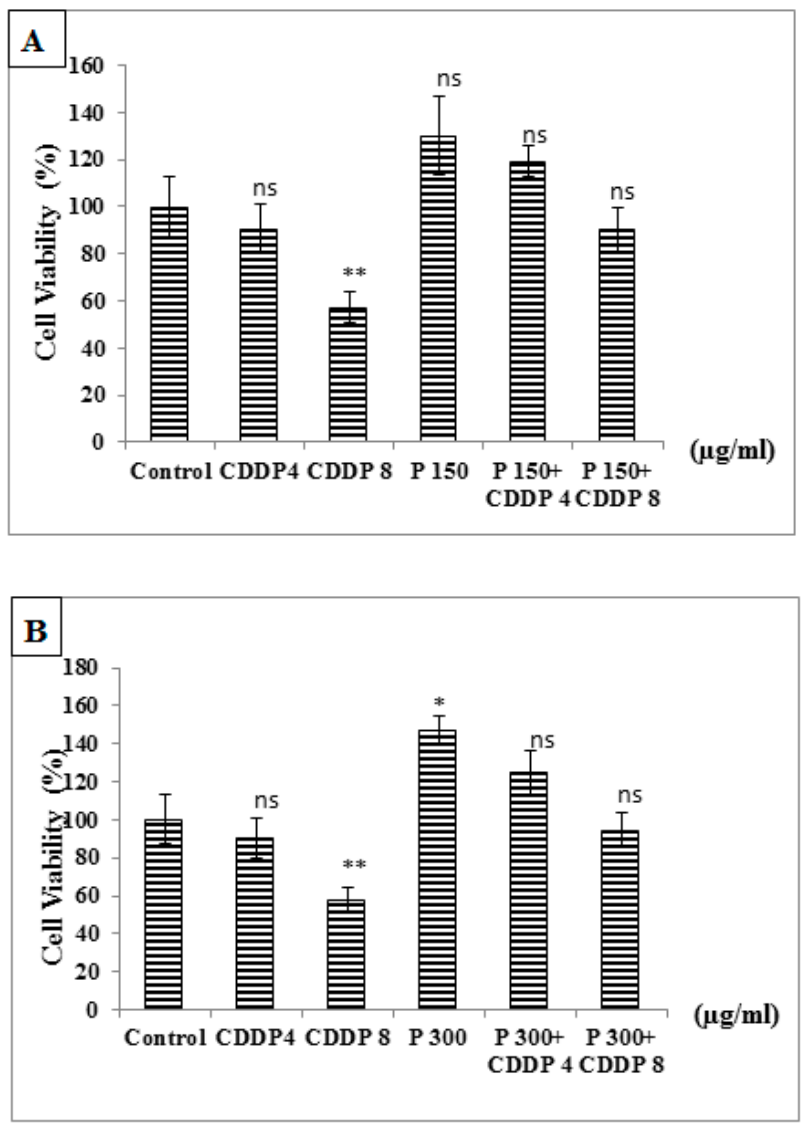

Figure 6. (A,B) Effect of combining pomegranate with CDDP on cell viability of control normal PBMC cells after $24 \mathrm{~h}$ of treatment. ns: non significant $p>0.05,{ }^{*} p<0.05,{ }^{* *} p<0.01$ in comparison to control. The number of samples is $n=4$. (CDDP: cisplatin, P: pomegranate juice).

\section{Discussion}

Lung cancer is the leading cause of cancer-related mortality around the world. About half of patients diagnosed with lung cancer die within one year of diagnosis. Several therapeutic modalities have been used recently to treat cancer patients such as surgery, chemotherapy, radiotherapy, and even targeted therapies. Among these, chemotherapy is one of the main treatments used for cancer patients; but this treatment causes many side effects that range from mild to severe, and may be even fatal [19].

Different studies on pomegranate have revealed its antineoplastic effect [20-22]. Patients treated with CDDP alone or in combination with other chemotherapeutic drugs may be exposed to serious adverse effects $[4,23,24]$. Hence, the goal of our study is to minimize the dose of CDDP and compensate it by combining pomegranate juice extract.

In this study, the combination of pomegranate juice extract (cultivated from Nmairieyh, South Lebanon of $400 \mathrm{~m}$ altitude) with different concentration of CDDP showed a higher antiproliferative effect on A549 cancer cells than pomegranate juice, cultivated form Baalbek, Lebanon (1170 m of altitude), combined with low-doses of CDDP and taxotere reported in our previous study [13]. The qualitative phytochemical screening tests showed the presence of different bioactive compounds-including alkaloids, terpenoids, and phenols-that might be responsible for the anticancer and antioxidant activities of pomegranate. Those results are generally in agreement with more detailed studies concerning the composition of pomegranate (Table 4) [25]. 
Table 4. Different classes of phytochemicals identified from pomegranate juice.

\begin{tabular}{|c|c|}
\hline Classes & Phytochemicals \\
\hline $\begin{array}{l}\text { Ellagitannins, } \\
\text { gallotannins, } \\
\text { and derivatives }\end{array}$ & $\begin{array}{c}\text { Brevifolin, Brevifolin carboxylic acid, Brevifolin carboxylic acid } \\
\text { 10-monopotassium sulphate, Castalagin, Casuariin, Casuarinin, Corilagin, } \\
\text { Isocorilagin, Hippomanin A, Gemin D }\end{array}$ \\
\hline Flavonoids & $\begin{array}{l}\text { Rutin (Quercetin-3-O-rutinoside), Quercetin-3,40-dimethyl ether } \\
\text { 7-O-_-L-arabinofuranosyl(1-6)-_-D-glucoside, Cyanidin, Chrysanthemin } \\
\text { (Cyanidin-3-O-glucoside), Cyanin (Cyanidin-3,5-di-O-glucoside), } \\
\text { (Procyanidin A2, Procyanidin B1, Procyanidin B2, Procyanidin B3 }\end{array}$ \\
\hline Lignans & Conidendrin, Isohydroxymatairesinol, Isolariciresinol, Matairesinol \\
\hline $\begin{array}{l}\text { Triterpenoids and } \\
\text { phytosterols }\end{array}$ & Punicanolic acid, Ursolic acid, Campesterol, Cholesterol \\
\hline Fatty acids and lipids & Caproic acid (Hexanoic acid), Caprylic acid (Octanoic acid), Capric acid \\
\hline $\begin{array}{l}\text { Akaloids and } \\
\text { indolamines }\end{array}$ & $\begin{array}{c}N-\left(2^{\prime}, 5^{\prime}-\text { Dihydroxyphenyl }\right) \text { pyridinium chloride, Hygrine, Norhygrine, } \\
\text { Pelletierine, } N \text {-Methylpelletierine, Norpseudopelletierine, Pseudopelletierine, } \\
2-\left(2^{\prime}-\text { Hydroxypropyl }\right)-\Delta^{1} \text { piperideine, } 2-\left(2^{\prime}-\text { Propenyl }\right)-\Delta^{1} \text { piperideine, } \\
\text { Punigratane (2,5-Diheptyl-N-methylpyrrolidine), Sedridine, Melatonin, } \\
\text { Serotonin, Tryptamine }\end{array}$ \\
\hline $\begin{array}{l}\text { Organic acids and } \\
\text { phenolic acids }\end{array}$ & Ascorbic acid, Citric acid, Fumaric acid, L-Malic acid, Oxalic acid, Quinic acid \\
\hline
\end{tabular}

DPPH antioxidant and phenol content testing showed the antioxidant activity of pomegranate juice. The antioxidant activity of DPPH was more efficient with methanol than with ethanol. This finding suggests that methanol has the strongest antioxidant activity in pomegranate extract [13]. The total phenol content of pomegranate juice extract was found to be elevated. This was slightly higher than the results previously reported by Ricci et al. [26]. A difference that may be due to cultivar or growth conditions [27].

Caravaca et al. reported 151 phenolics, 65 anthocyanin, anthocyanin-flavanol, and flavanol-anthocyanin adducts in pomegranate juice from Spain [28].

The treatment of A549 cells for $24 \mathrm{~h}$ with lyophilized pomegranate juice in a dose dependent manner decreased their viability which reflects the anticarcinogenic activity of pomegranate.

Pabla and Dong showed that treatment with CDDP alone was not completely harmless [23]. Hence, minimizing chemotherapeutic drug dosages and combining it with pomegranate might attenuate their side effects while maintaining the same antineoplastic activity. In this study, when pomegranate $(150 \mu \mathrm{g} / \mathrm{mL})$ was combined with low dose of CDDP $(8 \mu \mathrm{g} / \mathrm{mL})$, cell viability decreased by $33 \%$. While, cell viability decreased by $64 \%$ when pomegranate $(300 \mu \mathrm{g} / \mathrm{mL})$ was combined to the same dose of CDDP when compared to CDDP or pomegranate juice alone. Thus, pomegranate enhanced the antineoplastic effect of low dose of CDDP. In line with these results, Yu et al. showed that flavonoid significantly enhanced the chemosensitivity of CDDP in vivo and in vitro. They found that A549/CDDP (resistant to CDDP) cells not only acquired epithelial-mesenchymal transition (EMT) phenotype, but also showed increased NF-kB activity compared with A549 cells (sensitive to CDDP).

Zhao et al. showed that these compounds increase the production of IL-21 expressed in CD8, NK cells, and B cells which induce division and proliferation of these cells [29]. In addition, pomegranate extract increased the ratio of the $\mathrm{CD} 4+: \mathrm{CD} 8+\mathrm{T}$ cell subpopulations in peripheral blood mononuclear cells and inhibited apoptosis of PBMC [30].

Turrini et al. [10] studied the mechanism of action of pomegranate used in the treatment of different types of cancer. It has an antioxidant activity by decreasing reactive oxygen species and increasing glutathione S-transferase. It induces apoptosis by increasing the level of caspace-3, -8 , and -9 and decreasing the level of survivin. Pomegranate also plays an important role in inhibiting angiogenesis and metastasis by decreasing the level of the vascular endothelial growth factor (VEGF) [10]. 
The current results corroborated with the hypothesis that pomegranate, not only enhance antineoplastic effect of CDDP, but may also preserve normal PBMC, in a dose dependent manner. These results might be secondary to the presence of polyphenols in pomegranate juice that may induce the PBMC proliferation.

\section{Conclusions}

This study showed that pomegranate juice contains active compounds such as polyphenols, which induce significant anti-cancer activities against A549 cells. In addition, pomegranate juice may enhance the antineoplastic activity of low dose CDDP on A549 lung adenocarcinoma cells. In addition, we have highlighted that pomegranate juice might preserve normal PBMC from the cytotoxic effect of cisplatin; thus, adding pomegranate to cisplatin may increase the antineoplastic effect of CDDP and attenuate blood toxicity. Nevertheless, in vivo researches are needed to confirm these results.

Author Contributions: Conceptualization M.N. (Mohamed Nasser), A.H., R.D., Z.D., O.M., and M.N. (Mouhamed Nasser); Methodology B.A.-K., M.N., and C.T.; Software M.N. (Mohamed Nasser), C.T., and N.H.; Validation. C.T., R.D., A.H., B.A.-K., M.N. (Mohamed Nasser) and M.N. (Mouhamed Nasser); Formal analysis, M.N. (Mohammed Nasser) and C.T.; Investigation, B.A.-K., C.T., M.N. (Mohamed Nasser), A.H., and R.D.; Writing-original draft preparation, R.D., M.N. (Mohamed Nasser), C.T., N.H., A.H., and M.N. (Mouhamed Nasser); Writing-review and editing, C.T., O.M., A.H., and M.N. (Mouhamed Nasser); Supervision, M.N. (Mohamed Nasser), A.H., and Z.D.; Project administration, A.H. and O.M.; Funding acquisition, Z.D., A.H., and O.M. All authors have read and agreed to the published version of the manuscript.

Funding: This work is supported by the Lebanese university and by the French Foreign Ministry trough the Hubert Curien Project-Cèdre no. 42232RE.

Acknowledgments: This work is supported by the Lebanese University and by the French Foreign Ministry trough the Hubert Curien Project-Cèdre no. 42232RE.

Conflicts of Interest: The authors declare no conflict of interest.

\section{References}

1. Dela Cruz, C.S.; Tanoue, L.T.; Matthay, R.A. Lung cancer: Epidemiology, etiology, and prevention. Clin. Chest Med. 2011, 32, 605-644. [CrossRef] [PubMed]

2. Molina, J.R.; Yang, P.; Cassivi, S.D.; Schild, S.E.; Adjei, A.A. Non-small cell lung cancer: Epidemiology, risk factors, treatment, and survivorship. In Mayo Clinic Proceedings; Elsevier: Amsterdam, The Netherlands, 2008; Volume 83, pp. 584-594. [CrossRef]

3. Evans, M. Lung cancer: Needs assessment, treatment and therapies. Br. J. Nurs. 2013, 22, S15-S16. [CrossRef] [PubMed]

4. Dasari, S.; Tchounwou, P.B. Cisplatin in cancer therapy: Molecular mechanisms of action. Eur. J. Pharmacol 2014, 740, 364-378. [CrossRef]

5. Florea, A.M.; Busselberg, D. Cisplatin as an anti-tumor drug: Cellular mechanisms of activity, drug resistance and induced side effects. Cancers 2011, 3, 1351-1371. [CrossRef] [PubMed]

6. Astolfi, L.; Ghiselli, S.; Guaran, V.; Chicca, M.; Simoni, E.; Olivetto, E.; Lelli, G.; Martini, A. Correlation of adverse effects of cisplatin administration in patients affected by solid tumours: A retrospective evaluation. Oncol. Rep. 2013, 29, 1285-1292. [CrossRef] [PubMed]

7. Nasser, M.; Cheikh-Ali, H.; Hijazi, A.; Merah, O.; Al-Rekaby, A.; Awada, R. Phytochemical Profile, Antioxidant and Antitumor Activities of Green Grape Juice. Processes 2020, 8, 507. [CrossRef]

8. Makki, R.; Rammal, H.; Farhan, H.; Nasser, M.; el Dirani, Z.; Hijazi, A.; Badran, B. The antioxidant and anti-tumor activities of the Lebanese Centranthus Longiflorus LThe antioxidant and anti-tumor activities of the Lebanese Centranthus Longiflorus L. World J. Pharm. Sci. 2015, 3, 347-354.

9. Nasser, G.; Sabbah, A.; Chokeir, N.; Hijazi, A.; Rammal, H.; Issa, M. Chemical composition and antioxidant capacity of Lebanese molasses pomegranate. Am. J. Pharm. Tech. Res. 2017, 7, 191-204.

10. Turrini, E.; Ferruzzi, L.; Fimognari, C. Potential Effects of Pomegranate Polyphenols in Cancer Prevention and Therapy. Oxid. Med. Cell Longev. 2015, 2015, 938475. [CrossRef]

11. Al-Dujaili, E.; Abu Hajleh, M. Article Anti-Cancer Activity of Pomegranate and its Biophenols. EC Nutr. $2016,6,28-52$. 
12. Bassiri-Jahromi, S. Punica granatum (Pomegranate) activity in health promotion and cancer prevention. Oncol. Rev. 2018, 12, 345. [CrossRef] [PubMed]

13. Mohamad, N.; Hijazi, A.; Bouchra, S.; Zeinab, J.; Sajida, I.; Rammal, H.; Abd-El-Ameer, A.; Mohammed, N. Efficiency of combining pomegranate juice with low-doses of cisplatin and taxotere on A549 human lung adenocarcinoma cells. Asian Pac. J. Trop. Biomed. 2018, 8, 19. [CrossRef]

14. Mohamad, N.; As-sadi, F.; Fatima, J.; Hussein, K.; Hijazi, A.; Ali, C.; Hassan, R. Antibacterial, antioxidant and antiproliferative activities of the hydroalcoholic extract of the lebanese plant: Ephedra campylopoda. Int Res. J. Pharm. 2017, 7, 23-29. [CrossRef]

15. Brand,W.; Cuvelier, W.; Berset, M.E. Use of a free radical method to evaluate antioxidant activity. LWT-Food Sci. Technol. 1995, 28, 25-30. [CrossRef]

16. Farhan, H.; Malli, F.; Rammal, H.; Hijazi, A.; Bassal, A.; Ajouz, N.; Badran, B. Phytochemical screening and antioxidant activity of Lebanese Eryngium creticum L. Asian Pac. J. Trop. Biomed. 2012, 2, S1217-S1220. [CrossRef]

17. Mannerström, M.; Toimela, T.; Sarkanen, J.R.; Heinonen, T. Human BJ Fibroblasts is an Alternative to Mouse BALB/c 3T3 Cells in in vitro Neutral Red Uptake Assay. Basic Clin. Pharmacol. Toxicol. 2017, 121, 109-115. [CrossRef]

18. Jahanban-Esfahlan, A.; Ostadrahimi, A.; Tabibiazar, M.; Amarowicz, R. A Comparative Review on the Extraction, Antioxidant Content and Antioxidant Potential of Different Parts of Walnut (Juglans regia L.) Fruit and Tree. Molecules 2019, 24. [CrossRef]

19. Arruebo, M.; Vilaboa, N.; Saez-Gutierrez, B.; Lambea, J.; Tres, A.; Valladares, M.; Gonzalez-Fernandez, A. Assessment of the evolution of cancer treatment therapies. Cancers 2011, 3, 3279-3330. [CrossRef]

20. Panth, N.; Manandhar, B.; Paudel, K.R. Anticancer Activity of Punica granatum (Pomegranate): A Review. Phytother. Res. 2017, 31, 568-578. [CrossRef]

21. El-Ashmawy, N.E.; Khedr, E.G.; El-Bahrawy, H.A.; Abd El-Fattah, E.E. Effect of Pomegranate Hull Extract on Liver Neoplastic Changes in Rats: More than an Antioxidant. Nutr. Cancer 2016, 68, 1044-1051. [CrossRef]

22. Jaganathan, S.; Vellayappan, M.V.; Narasimhan, G.; Supriyanto, E. Role of pomegranate and citrus fruit juices in colon cancer prevention. WJG 2014, 20, 4618-4625. [CrossRef]

23. Pabla, N.; Dong, Z. Cisplatin nephrotoxicity: Mechanisms and renoprotective strategies. Kidney Int. 2008, 73, 994-1007. [CrossRef] [PubMed]

24. Oun, R.; Moussa, Y.E.; Wheate, N.J. The side effects of platinum-based chemotherapy drugs: A review for chemists. Dalton Trans. 2018, 47, 6645-6653. [CrossRef] [PubMed]

25. Wu, S.; Tian, L. Diverse Phytochemicals and Bioactivities in the Ancient Fruit and Modern Functional Food Pomegranate (Punica granatum). Molecules 2017, 22. [CrossRef]

26. Ricci, D.; Giamperi, L.; Bucchini, A.; Fraternale, D. Antioxidant activity of Punica granatum fruits. Fitoterapia 2006, 77, 310-312. [CrossRef]

27. Sayed, B.; Talou, T.; Saad, Z.; Hijazi, A.; Cerny, M.; Kanaan, H.; Chokr, A.; Merah, O. Fennel oil and by-products seed characterization and their potential applications. Ind. Crops Prod. 2018, 111, 92-98. [CrossRef]

28. Caravaca, A.M.G.; Verardo, V.; Toselli, M.; Segura Carretero, A.; Fernández-Gutiérrez, A.; Caboni, M. Determination of the major phenolic compounds in pomegranate juices by HPLC-DAD-ESI-MS. J. Agric. Food Chem. 2013, 61. [CrossRef]

29. Zhao, F.; Pang, W.; Zhang, Z.; Zhao, J.; Wang, X.; Liu, Y.; Wang, X.; Feng, Z.; Zhang, Y.; Sun, W.; et al. Pomegranate extract and exercise provide additive benefits on improvement of immune function by inhibiting inflammation and oxidative stress in high-fat-diet-induced obesity in rats. J. Nutr. Biochem. 2016, 32, 20-28. [CrossRef]

30. Magrone, T.; Jirillo, E.; Spagnoletta, A.; Magrone, M.; Russo, M.A.; Fontana, S.; Laforgia, F.; Donvito, I.; Campanella, A.; Silvestris, F.; et al. Immune Profile of Obese People and in vitro Effects of Red Grape Polyphenols on Peripheral Blood Mononuclear Cells. Oxid. Med. Cell. Longev. 2017, 2017, 9210862. [CrossRef] [PubMed]

Publisher's Note: MDPI stays neutral with regard to jurisdictional claims in published maps and institutional affiliations. 
(C) 2020 by the authors. Licensee MDPI, Basel, Switzerland. This article is an open access article distributed under the terms and conditions of the Creative Commons Attribution (CC BY) license (http://creativecommons.org/licenses/by/4.0/). 